\title{
Communication Action Zones in Art and Technology - ZACAT
}

\author{
Keywords \\ Contemporary Art, Art and Technology, Art Activism, Art and Communication, Device.
}

Communication Action Zones in Art and Technology, in portuguese Zonas de Ações Comunicacionais em Arte e Tecnologia - ZACAT - is a master's research developed in Brazil, made before and during the SARS-CoV-2 virus pandemic, which causes the New Coronavirus disease. This artistic and academic work includes a set of sound and visual poetics based on an investigation of artistic communicational practices of an activist character, with the mediation of several questions about the current Brazilian history. Firstly, through diversified strategies and proposals for different interlocutors, with experiments in 2019, in different spaces in the city of Santa Maria, state of Rio Grande do Sul - streets, museums, art galleries, university, school, social networks, radio wave space. Subsequently, as a result of the world scenario presented from 2020, with the COVID-19 pandemic, the poetic undergoes significant transformations. In addition to the artistic and communicational strategies undergoing changes in approach, the Santa Maria space moves to that of the Clube Naturista Colina do Sol (CNCS), a naturist community located in the municipality of Taquara, also in Rio Grande do Sul. Not urbanized and immersed with the wild environment the least interfered by human action, which provides other forms of listening and connection, in addition to the relationship with the body, communication and technology, such as the use of online virtual reality platforms to share the work carried out.
To approach the construction of this research, studies on methodology by the researcher and artist Sandra Rey (1953) are used. As a theoretical foundation, reference is made to the idea of micropolitics, a concept that refers to philosophers Michel Foucault (1926-1984) and Gilles Deleuze (1925-1995) and to art critic Suely Rolnik (1948). Activist artistic practices are based on the experiences of Brazilian collectives from the 1990's to the present, as seen under the historiography of Art Activism from the 1950's, with Italian autonomist philosophers such as Giorgio Agamben (1942) and Franco Berardi (1949). To support the notion of Art and Communication, authors such as Mario Costa (1936), Fred Forest (1933), Mônica Tavares, Priscila Arantes, Christine Mello and Giselle Beiguelman are based on. The concept of device emerges from theoretical research and mediates artistic practices, having as reference Agamben, Foucault, Vilém Flusser (1920-1991) and Gilbert Simondon (1924-1989). From performances, through installations, through audio, video and face-to-face interactivity experiments or via virtual networks, this research seeks to give visibility to everyday micropolitics, with their memories, affections, formalized or ephemeral life impulses in moments of encounters. And how the artistic works can unfold in different contexts, in front of different audiences and under challenging conditions in terms of a larger historical context. 